\title{
TOWARDS AN IMPROVED APPLICATION OF EUROPEAN UNION LAW IN LITHUANIA: THE EXAMPLES OF COMPETITION LAW AND INTELLECTUAL PROPERTY LAW
}

\begin{abstract}
Yvonne Goldammer \& Elzé Matulionyté*
Summary: Although both the Lithuanian authorities and Lithuanian courts had already started to apply EC law well before accession, the quality of application of EC law and the frequency of its use have only improved within the last two years. Nevertheless, there is still room and need for improvement in this area before proper application of EC law in all sectors is achieved. This article analyses some cases decided by the Lithuanian authorities and the highest Lithuanian courts for both administrative and general jurisdiction, mainly in the fields of competition law and intellectual property law. Summarising the application of EC law by the Lithuanian Supreme Court in the area of civil jurisdiction, particularly intellectual property rights, on the one hand, and the Lithuanian Supreme Administrative Court and the Lithuanian Competition Council, with a special focus on competition law, on the other, the authors contend that the application of EC law in the areas under consideration is far from ideal. In most cases, courts have not yet developed a general view of Community law as a sui generis system of law. There are still difficulties in distinguishing between EC law and ordinary international law. Instead of referring to the specific nature of EC law, which is accepted in both constitutional jurisprudence and national legislation, courts treat EC law as something analogous to international law. The principles set forth by the ECJ concerning the 'ideal' application of Community law by the national judiciary have apparently not yet been fully comprehended by Lithuania's courts. While they seem to have learned that supremacy must be given to EC law, in most cases they are unable to consistently incorporate reasoning based on such supremacy into their judgments. However, when these two 'pioneer' fields of EC law application are analysed, it is obvious that changes are gradually occurring. The first examples of application by both supreme courts were very poor ones, lacking a systematic approach to application and insufficient in both quality and quantity. The development of case law in trademark disputes permits a more positive evaluation, while in the area of competition law EC law has begun to be applied much more purposefully. ECJ case law is being referred to, and arguments by the
\end{abstract}

\footnotetext{
* Yvonne Goldammer \& Elzé Matulionyté, Assistants in the International and European Law Department of the Faculty of Law at Vilnius University, Lithuania.
} 
parties based on EC law are given due consideration. Still, these two areas represent the most well-developed ones, while similar progress has not yet been seen in other fields of EC law. Hopefully, satisfactory practice in the fields considered here will spill over into a more general awareness of EC law and, accordingly, its proper application. Since 'the will' to apply EC law seems to exist on the part of national courts and institutions, 'the way' to apply it correctly must also be found. For the moment, the way is time, training and practice.

\section{Introduction}

Ten new Member States (no longer the newest) are already celebrating the third anniversary of their accession to the European Union. Upon accession, these new members not only had to remodel their legal systems by implementing the acquis communautaire, but were now also obliged to apply EC law in practice. Taking into account both the volume of EC law relevant to everyday legal practice and the specific conditions for its application, this task has proved to be much more complicated than the copy-paste technique of 'implementing' the acquis.

Lithuania has consistently been among those Member States with the best record of formal integration of EC law into its national law, ${ }^{1}$ and to date no infringement procedure against it has reached the judicial stage. ${ }^{2}$ When analysing the decisions of Lithuanian courts, however, one realises that proper enforcement of EC law still requires much effort. National courts need to further deepen their knowledge of the functioning of EC law, become more familiar with the relevant case law, understand the complex relationships between national and European law, and eliminate tensions that could occur when enforcing European provisions in the domestic legal system. ${ }^{3}$ It is obviously not enough for courts to merely know the relevant European legislation; rather, they must also find the right approach to its application, make use of the available national and

1 See eg the Commission's Internal Market Scoreboards nos 14, 14 bis, 15, 15 bis <http:// ec.europa.eu/internal_market/score/index_en.htm> accessed 15 April 2007.

2 On 22 March 2007 the Commission announced that it was bringing an action against Lithuania in a new round of proceedings for infringement of EU telecom rules, namely deficiencies with the emergency number 112 (Commission Press Release IP/07/392, 22 March 2007). However, as of 25 May 2007 no notice regarding this action had been published in the OJ.

3 See also Egidijus Kūris, 'Lietuvos Respublikos Konstitucija ir Europos teisès iššūkiai' ['The Constitution of the Republic of Lithuania and the challenges of European law'] (2004) Justitia 37; for an evaluation of factors influencing the work of the Supreme Administrative Court of Lithuania, see Virgilijus Valančius, 'Lietuvos administraciniai teismai: pirmieji ispūdžiai taikant ES teisę' ['Lithuanian Administrative Courts: First impression applying EC law’] (2004) Justitia 25-32. 
European legal resources with an awareness of their own legal situation and the competence to apply it, and be flexible enough to find the most appropriate way of achieving effective application and enforcement. ${ }^{4}$

This article aims to examine and evaluate the application of EC law by Lithuania's two highest courts - the Supreme Court ${ }^{5}$ and the Supreme Administrative Court ${ }^{6}$ - before and since accession, covering the period from January 2000 to April 2007.

\section{The Legal Basis For Applying European Union Law In Lithuania: A General Overview}

Before accession to the European Union, there were no formal grounds in Lithuanian law for applying EC law (with the exception of the Europe Agreement ${ }^{7}$ and competition law $^{8}$ ). Lithuania's Constitution only contained a provision concerning international treaties, ${ }^{9}$ which was more specifically defined by the Law on Treaties ${ }^{10}$ and interpreted by the Constitutional Court ${ }^{11}$ as grounds for applying international law. In preparing for EU accession, the Law on Courts, the Law on Administrative Litigation, the Civil Procedure Code and the Criminal Procedure Code were amended in 2003. These amendments, which were to enter into force on

\footnotetext{
4 Phedon Nicolaides, 'Preparing for Accession to the European Union: How to Establish Capacity for Effective and Credible Application of EU Rules' in Marise Cremona (ed), The Enlargement of the European Union (Academy of European Law, European University Institute, Oxford 2003) 56-60.

5 Hereinafter also LSC.

6 Hereinafter also LSAC.

7 The Europe Agreement establishing an association between the European Communities and their Member States, for the one part, and the Republic of Lithuania, for the other part ([1998] OJ L51/3) entered into force on 1 February 1998, and was directly applicable, at least in theory, since Lithuania has a monistic system with regard to the effect of international treaties.

8 As early as in 1999, Art 1(3) of Lithuania's Competition Law explicitly stated one of its purposes as seeking to harmonise Lithuania's competition policy with European Union law (Official Gazette 1999, no 30-856). On this basis, the Lithuanian Competition Council has taken decisions by European courts and the Commission and their interpretation into account when applying the Competition Law.

9 Art 138 para 3 of the Lithuanian Constitution reads: 'International treaties ratified by the Seimas of the Republic of Lithuania shall be a constituent part of the legal system of the Republic of Lithuania' (Official Gazette 1992, no 33-1014; official English translation available at <http://www3.1rs.lt/pls/inter3/dokpaieska. showdoc_1?p_id=275302> accessed 30 March 2007).

10 Official Gazette 1999, no 60-1948.

11 The Constitutional Court's opinion of 24 January 1995 on accession to the EHRC (Official Gazette 1995, no 9-199). Although in this earliest ruling the Constitutional Court interpreted Art 138 para 3 of the Constitution as taking a monist approach only to international treaties ratified by the Seimas, later the general conclusion was drawn that Lithuania takes a monist approach to all international law (see Decision of the Constitutional Court of 14 March 2006, no 17/02-24/02-06/03-22/04).
} 
the day of accession to the EU, provided the basis for national courts to apply EC law in cases brought before them. ${ }^{12}$ The amended national laws and legal codes thus stated that a court hearing a case should also apply EC law and be guided by the decisions of European institutions and the preliminary rulings of the ECJ. Moreover, these amendments introduced a clause 'allowing' national courts to refer a preliminary question to the ECJ, in cases where its ruling is needed by a national court hearing a case that involves some unclear point of EC law. ${ }^{13}$ These amendments introduced some precision regarding the basis in national law for the application of EC law. ${ }^{14}$ However, such special provisions enabling national courts to make reference to ECJ rulings were no longer necessary following EU accession, since the obligation to apply EC law, and especially the obligation to refer questions to the ECJ, derives from EC law itself, irrespective of whether any ground for it exists in national law.

Shortly after accession, the Constitutional Act on Membership of the Lithuanian Republic in the EU, supplementing the Lithuanian Constitution, was also adopted; among other things, it provides that EC law is a constituent part of Lithuania's legal system. ${ }^{15}$ Moreover, the Constitutional Act provides that EC law must be applied directly if such application follows from the Founding Treaties, and grants EC law supremacy over national law in the event of a conflict. ${ }^{16}$ By adopting the Constitu-

12 Law of 8 April 2003 amending the Law on Courts, the Law on Administrative Litigation, the Civil Procedure Code and the Criminal Procedure Code (Official Gazette 2003, no 391765).

13 There is, however, another interesting provision in this amendment relating to the duty of the LSC and the LSAC to ensure uniform application of European Community law by lower courts. According to this provision, the LSC and the LSAC are entitled to examine the practice of lower courts in applying EC law and make recommendations on how uniform interpretation and application of this law in Lithuania is to be ensured (Art 1 and Art 3 of Chapter I, Art 1 of Chapter 2, and Art 1 of Chapter 3 of the aforementioned law (n 12)). This quasi-administrative function of 'recommendation' by the highest courts is a relict of the Soviet legal system, where the highest court performed not only judicial functions, but also administrative ones, ie supervising lower courts. Although modified, this function remains in the Lithuanian court system today. The LSC and the LSAC are authorised to summarise the practice of lower courts, which in practice means that they choose a certain area of law, examine the judgments of lower courts, and publish formally non-binding reviews, resolutions and consultations on certain aspects of application of the law.

14 This provision, stipulating the obligation to apply EC law, has been used by the courts (eg the LSC's Decision of 29 December 2006, no 3K-3-690/2006) rather than the ECJ's case law on this obligation (for more details, see $\mathrm{n} 40$ below).

15 Constitutional Act on Membership of the Lithuanian Republic in the EU (Official Gazette 2004, no 111-4123).

16 For a more detailed discussion, see Vilenas Vadapalas, Irmantas Jarukaitis: 'Constitution of the Republic of Lithuania, International Law and Accession to the European Union' in Francisco F Segado (ed) The Spanish Constitution in the European Constitutional Context (Madrid 2003) 473-488; Irmantas Jarukaitis, 'New Member States: Lithuania' in Alfred E Kellerman (ed), The Impact of EU Accession on the Legal Orders of New EU Member States and (Pre-)Candidate Countries (The Hague, 2006) 385-407. 
tional Act, which forms an integral part of the Constitution, the Lithuanian Parliament confirmed again (as in the aforementioned amendments to the procedural codes, which set forth the obligation to apply EC law) its conviction that the basis for applying EC law derives from the Constitution itself. Although the Constitutional Act formalised the application of EC law and its supremacy, in line with how these principles have been developed by the ECJ, it also rejected the idea that the application of EC law proceeds from EC law itself. ${ }^{17}$

As discussed below, however, 'ordinary' national courts have paid little attention to the question of whence the obligation to apply EC law originates. There has not yet been a single case in which a court referred to the Constitutional $\mathrm{Act}^{18}$ or relied on its provisions establishing the constitutional background for applying EC law. Moreover, it seems that the amendments and clauses concerning the application of EC law introduced into the national procedural codes and the Constitutional Act have not influenced the reasoning of national courts. Rather, these courts have applied EC law based on the very fact (once future, now actual) of EU accession.

\section{EC Law in the Case Law of the Lithuanian Supreme Court}

Being the older and thus more 'genuine' of Lithuania's two highest courts, the Lithuanian Supreme Court (LSC) has not been keen to give up its leading jurisdictional role to its counterpart, the Lithuanian Supreme Administrative Court (LSAC). Since the LSC had begun applying European Community law in its rulings well before accession, and had done so quite willingly, it could be considered a court with highly pro-European convictions. As the saying goes, however, "the road to hell is paved with good intentions'; and even the enthusiasm and goodwill to do something does not always (or, as in the case of the LSC's application of Community law, not immediately) lead to good results. Despite its pro-European activism, quite a few of the LSC's early attempts to deal with EC law (both before and after accession) were inconsistent, unsystematic and, in many instances, even quite inaccurate.

\footnotetext{
17 I Jarukaitis, 'The Adoption of the Third Constitutional Act and Its Impact on the National Constitutional System' (2006) 60 Teise: mokslo darbai 29.

18 Except for the Constitutional Court itself, which has found an opportunity to interpret the Constitutional Act and given its position on the impact of EC law in the national legal system twice already (Decision of 14 March 2006 on the use of certain land, no 17/0224/02-06/03-22/04, and Decision of 21 December 2006 on the financing of national radio and television, no 30/03).
} 


\section{Before Accession}

The very first case in which the LSC referred to something like European Community law (Sirowa) was already decided in 1998. ${ }^{19,20}$ The applicant sought to have a decision imposing a fine for the misleading labelling of a medicinal product annulled (administrative courts had not yet been established at that time, and so courts of general jurisdiction also reviewed the legality of administrative decisions). Analysing the definition of medicinal products, the LSC briefly noted that both the definition of a medicinal product and the labelling requirements for such products under national legislation corresponded in principle with the relevant Community directives. ${ }^{21}$ Nothing more was said about EC law and, in particular, no explanation was given as to why it was of any importance that definitions under national law be the same as European ones. In the second case (Birštono mineraliniai vandenys, decided in 2000), ${ }^{22}$ the Supreme Court likewise merely cited the definitions of designation of origin and geographical indication given in the GI Regulation, ${ }^{23}$ without any explanation of why it was referring to EC law and on what grounds. The Court did not elaborate any arguments relating to Community law; rather, it used these definitions merely as a comparative and interpretative source of law, since the national law on trademarks in force at the time did not contain such definitions. The LSC stated that although national law did not contain definitions of designation of origin and geographical indication, some 'international documents' (meaning the EC Regulation) defined these concepts. Apart from giving a first signal that the LSC regarded EC law as ordinary international public law, nothing significant for the 'application' of EC law by Lithuanian courts was said in this case, either. Obviously, these two examples could hardly be termed an 'application' of Community law. The LSC simply cited EC law provisions that were either analogous to the parallel national provision or (as in the geographical indications case) suitable for filling a gap in the national legislation where there was no corresponding national provision. The Court neither looked at the substance of the European norm and its meaning

\footnotetext{
19 The case law of the Lithuanian Supreme Court may be accessed at <www.lat.lt $>$; however, the decisions are available in Lithuanian only.

20 Judgment of the LSC of 14 September 1998 in Sirowa, no 3K-53/98.

21 Council Directive (EEC) 92/27 on the labelling of medicinal products for human use and on package leaflets [1992] OJ L113/8, and Council Directive (EEC) 65/65 on the approximation of provisions laid down by law, regulation or administrative action relating to proprietary medicinal products [1965] OJ L22/369.

22 Judgment of 25 January 2000 in Birstono mineraliniai vandenys, no 3K-3-25/2000.

23 Art 2(2) Council Regulation (EEC) 2081/92 on the protection of geographical indications and designations of origin for agricultural products and foodstuffs [1992] OJ L208/1.
} 
in detail, nor dealt with the more general question of why it should apply such European law at all. ${ }^{24}$

Only in its third 'EC law case' - the Budejovicky Budvar case, ${ }^{25}$ also decided in 2000 - was the LSC more precise as to the reasons why it was referring to Community law before accession. This case, therefore, served as a precedent ${ }^{26}$ for all later cases in which EC law was mentioned (including some cases after accession). The LSC analysed the issue of confusion among consumers in detail, and based a large part of its argumentation on EC law, as interpreted in the relevant practice of the ECJ. Only after having cited the relevant provisions of EC law in its decision (together with ECJ case law) did the LSC turn to the more substantial question: namely, the reasons and basis for applying Community law in the case before it. The Court's argument was framed as follows:

[T]aking into account the fact that contemporary intellectual property rights are the outcome of a long process of unification and harmonisation in this area, and considering Lithuania's objective of joining the EU and the need, resulting from this objective, to harmonise national law with EC law, the provision of the national Trademark Law [...] must be interpreted in the light of EC law. ${ }^{27}$

Thus the main rationale for referring to Community law was, according to the Supreme Court, Lithuania's goal of EU accession. In the opinion of Lithuanian scholars, the LSC tried by means of this case to send a message to lower courts, suggesting that they analyse whether a national provision at issue originated from EC law and, if so, that they interpret and apply this provision according to EC law. ${ }^{28}$ However, if this was indeed the LSC's aim, it was not well reflected in the judgment itself. EC law was referred to merely as an interpretative tool enabling a national

\footnotetext{
24 However, to be fair one must mention that Sirowa (n 20) was actually a landmark judgment in the sense that Lithuanian courts used the principle of proportionality in their argumentation for the first time, thus starting a qualitative shift away from purely formalistic reliance on a written norm.

25 Judgment of 17 May 2000 in Anheuser-Busch Inc. v Budejovicky Budvar n.p., no 3K-3$554 / 2000$, the Lithuanian version of the worldwide trademark dispute between the Czech Budweiser beer and its American counterpart.

26 In the national legal system, precedents are not formally a source of law, although the significance of judgments by the Supreme Court as an interpretative tool is growing. Virgilijus Valancius (ed), Commentary on the Code of Civil Procedure of Lithuania, Part I-Common Provisions (Justitia, Vilnius 2004) 44-45.

27 Sirowa (n 20). Similar statements were also made in later case law, eg Judgment of 7 January 2003 in Smirnova, no 3K-3-167/2003, and Judgment of 15 December 2003 in Beecham Group, no 3K-3-1103/2003.

28 M Mikelenas, 'Europos Sajungos teisès (ir valstybès atsakomybės principo) taikymas Lietuvos Respublikos bendrosios kompetencijos teismuose' ['Application of EC law in Lithuanian courts of general jurisdiction'] (conference materials) (Justitia, Vilnius 2006).
} 
court, particularly with the help of ECJ case law, to clarify concepts of national (trademark) law which had no precise meaning in that law. The LSC neither attempted nor, it would seem, found it necessary to examine whether EC law itself could be a source of law prior to EU accession. The LSC's case law would, in fact, support the opposite conclusion, since the LSC has never referred to Community law alone as a single legal source, but rather only in conjunction with one or several provisions of national or international law (such as the Paris Convention or TRIPS in trademark cases).

Given that the LSC has referred to Community law most often in conjunction with provisions from 'ordinary' international law, and also that the wording used in its judgments (for example, 'as [...] the Directive and other international law provides', ${ }^{29}$ or 'as explained by the practice of international courts', ${ }^{30}$ where the ECJ's case law was actually meant), it may be observed that the Court typically approaches EC law as ordinary international public law. Interestingly, the LSC has not found it necessary to differentiate between 'normal' international law (ie treaties to which Lithuania is a signatory) which, according to the Constitution, forms an integral part of the Lithuanian legal system, and EU directives and regulations. It is not clear if the Court considers EU directives and regulations similar to treaties (ie a source of international law) or recommendations adopted by international organisations (ie international soft-law). It could be that this disregard for the special character of EC law also stems from a general perception of the European Union as merely an international organisation, and nothing more. ${ }^{31}$ As a consequence of simply treating the EU as an international organisation, the laws adopted by its institutions are considered to be international law as well. On the other hand, placing Community law on an equal footing with international law has allowed the LSC to avoid going into detail as to why it should be applied. Moreover, it may be observed that even when the Court acknowledged the special character of EC law prior to accession, it was not clear what effects this should have had. At that time, national courts neither had an obligation to grant supremacy to EC law nor to apply it directly or with

29 Already in one of its first cases referring to EC law (namely, Birstono mineraliniai vandenys (n 22)) the Court gave an indication that it treats EC law as international law. Immediately after accession, it still repeated the same mantra, stating eg that 'such requirements are set forth in international law, ie Directive [...] and Regulation [...]' (see Judgment of 21 December 2004 in UAB Gurda $v$ UAB Narbutas ir Ko, no 2A-346/2004). The Court thus continued to ignore the specific nature of Community law.

30 Eg Budejovicky Budvar (n 25).

31 Such an argument is also maintained in the general discussion on the status and place of EC law in the national legal systems of the new Eastern European Member States and, in particular, the Baltic States. See Anneli Albi, "Europe” articles in the constitutions of Central and Eastern European countries' (2005) 45 CMLR 416-418. 
full effect. EC law was made use of as a comparative source of 'better law', without too many considerations of a more general character (if at all). This was probably the best that the Court could do, given the status of EC law prior to accession, and bearing in mind its understanding of EC law and the integration process.

Another dozen cases were decided by the Lithuanian Supreme Court with reference to EC law before accession, inviting the optimistic conclusion that Lithuanian courts were boldly preparing for their role as $\mathrm{Eu}-$ ropean courts. However, their method of 'applying' Community law most often amounted to simple citation. The LSC used the text of EC legislative acts only as a source of formal comparison with the corresponding Lithuanian provisions. It never examined what the provision of the EC law to which it 'referred' actually meant or what its purpose was, nor did it examine the relevant ECJ case law in detail, thus demonstrating a rather formalistic approach which took into account only what was explicitly set forth in the legislative act.

As already mentioned, the sphere of law where the LSC made use of EC law, at least as an interpretative instrument, in its own case law prior to accession was a rather narrow one, concerned almost exclusively with intellectual property rights (of the eighteen cases referring to EC law, fifteen were IPR cases); $;^{32}$ and even within this area, the disputes in question were limited mainly to trademark law. The reasons for such a narrow specialisation are several. First and perhaps foremost was the LSC's insufficient competence, knowledge and practice, compared to the ECJ's abundant and sophisticated case law. Not surprisingly, intellectual property rights law was also among those areas where considerable changes were needed in order for Lithuania to qualify for accession, creating the conditions for the four freedoms while ensuring adequate protection of IPR. While the national regulatory framework for intellectual property rights has been developing continuously, the need for improved enforcement by both institutions and courts has constantly been emphasised. ${ }^{33}$ In the late nineties, of course, the LSC was faced with an increasing number of cases related to the use and misuse of trademarks and the an-

32 There have only been a very few (three) cases in other fields of law where EC law was touched upon. The first, Sirowa, which has already been mentioned (n 20), dealt with definitions of a medicinal product. The second case concerned, among other things, spamming (Judgment of 10 October 2001 in Sékmés sistemos, no 3K-3-927/2001) and the third referred to the Second Company Law Directive (Judgment of 4 June 2003 in Adomaitis et al $v$ Mažeikių nafta, no 3K-3-650/2003). Whereas in the first two cases only an interpretative reference was made to EC law, in the third the LSC explained that it was referring to the Directive because the explanatory memorandum to the national law at issue indicated that it was implementing the Company Law Directives.

33 See the Commission's Annual Reports on Progress towards Accession <http://ec.europa. eu/enlargement/archives/enlargement_process/past_enlargements/eu10/lithuania_ en.htm> accessed 25 March 2007. 
nulment of their registration. Without waiting for the national Trademark Law to be fully harmonised with the Community's more comprehensive trademark legislation, the LSC sought assistance in the relevant provisions of EC law and, more importantly, ECJ practice. The Budejovicky Budvar case was already important not only for being the first where the LSC elaborated somewhat on the application of EC law in general, but also as a pilot case for all its later case law in the area of trademarks and other intellectual property rights. In fact, many later cases both before and immediately after accession followed the same pattern established in the Budejovicky Budvar case, referring to the same ECJ case law and never bothering to look at other abundant case law (eg more recent and relevant cases in a particular dispute).

To sum up, it could be argued that although the Lithuanian Supreme Court started applying Community law even before accession, the significance of such 'application' is rather arguable. Besides the fact that the LSC's application of EC law was limited almost exclusively to trademark cases, the Court did not set a clear rule explaining why EC law should be applied at all by Lithuanian courts, and in what manner.

\section{Since Accession}

During the first two years since accession, the same problems as before accession persisted in the LSC's case law. In addition to the fact that cases referring to EC law dealt with the same very limited area (trademark law), the LSC continued to neglect the specific nature of EC law in the first years after accession. Moreover, the very first attempts to apply Community law in areas other than trademark law immediately revealed all the problems that national courts, which were used to a plain text-based reading of the law, could and did face when forced to deal with EC directives.

One may also find certain indications that the first post-accession cases were pervaded by the accession euphoria that overwhelmed Lithuanian society in 2004. In the LSC's case law, this emerges in the form of a baseless eagerness to apply any Community law provision to which the parties might refer, despite its (probably) being irrelevant. Thus in 2004 the Court came up with some brilliant examples of how EC law should not be applied. It ignored the fact that the parties in a given case (both private individuals) referred to a directive more than a year before its implementation date, ${ }^{34}$ or that the event from which the dispute arose had happened well before accession ${ }^{35}$ (yet was not continuing at the time of

34 Judgment of 12 May 2004 in Lietuvos medicuinos darbuotojų profesinè sajunga, no 3K3-301/2004.

35 Namely, a public tender for purchasing certain products; see Judgment of 3 November 2004 in Vitrolabo servisas, no 3K-3-597/2004. 
the hearing, thus giving no cause for EC law to have any real effect). Although the Court's argumentation may look more impressive when supported by a larger number of different provisions, even those of EC law (!), it seems a little superfluous to cite everything with the same keywords without examining whether the given situation truly falls within the scope of a particular EC law provision.

Obviously, the core reason for such incorrect use of Community law lies in the LSC's insufficient competence in and knowledge of EC matters, despite its willingness to have a position regarding them. This could be seen during the first round of the national judges' training programme on EC law in $2004,{ }^{36}$ where the main message for judges was that they now had to apply EC law as well. However, they either overheard the part about how Community law was to be applied, or else this did not interest the people leading the courses. Moreover, if examined in greater depth it is clear that to a rather formalist judge, who normally just reads and applies legislative texts as such, it will seem quite unusual that certain conceptual pre-conditions (eg the direct applicability of directives, as developed by the ECJ) must be met in order for legislative provisions to be applied. It appears that the judges enthusiastically accepted the fact that they were now responsible for applying another 80,000 pages of legislative text, whether national or 'European', and started using them just like any other laws. The more general principles established by the ECJ regarding the functioning of Community law were not initially a concern. And least on their minds was the idea that the rationale behind Community law was, first and foremost, European integration, and that it was in this light that it should be interpreted and applied. Only at the very end of 2006 did the LSC refuse to directly apply the provisions of a directive on the ground that its implementation period had not yet expired at the time of the events in dispute, ${ }^{37}$ and that the preconditions for direct application of the directive had not been met - issues to which the lower court, whose decision was being appealed, had not paid attention.

Another point worth noting is that, during the first three years of its obligation to apply EC law, not one single aspect of EC law has posed the LSC with a serious enough question for it to make a preliminary reference. It would seem logical that, in the first years of dealing with a previously unknown volume of law (or one known only to a very limited extent), the Court would have many questions on this new law which it is now to apply. However, the LSC's practice demonstrates rather the opposite: the less one knows, the fewer questions one has. Even when making obvious mistakes concerning EC law, the LSC has never tried to seek

36 For more about the training of national judges, see note 90 below.

37 Judgment of 20 November 2006 in R. J. and T. R. v Viti, no 3K-3-592/2006. 
assistance from the ECJ. In its attempt to puzzle out EC issues on its own, the LSC has never recalled the CILFIT ${ }^{38}$ formula of acte clair, which states that a national court is freed from the obligation to refer if the correct application of EC law is so obvious that no reasonable doubt exists, not only for the referring court itself but also for the ECJ and the courts of other Member States (should they deal with the same matter). On the contrary, in relying merely on some provision of EC law (and not on ECJ case law with respect to this provision), the LSC has never explained why it believes that the scope and subject matter of the given provision should be interpreted as it does. The LSC's judges do not seem to worry that the provision to which they refer could have a different meaning for the ECJ. The LSC has neither made a single reference ex officio, nor acted on any request by the parties to a dispute to refer a question to the ECJ. ${ }^{39}$ In the only case where the LSC refused to make a preliminary request, its refusal was based on having already interpreted the matters in question in its earlier (pre-accession) case law, whose reasoning was based on ECJ case law. In light of the acte clair doctrine, such an excuse is obviously not valid, since the LSC's refusal to refer was not directly based on whether the ECJ's case law was clear on this issue, but rather on the fact that the LSC's case law on this issue was well-founded. However, three years after accession is obviously too short a period for launching a Köbler-type procedure for damages due to the erroneous application of EC law and failure to refer to the ECJ.

It was not until 2006 that the LSC had an opportunity to make its long-awaited more general statement regarding the application of Community law, having begun to analyse and reconsider the grounds for its application and questions of supremacy. However, the LSC has had difficulties in deciding on which particular grounds it must grant supremacy to Community law in its judgments. So far it has followed several quite different lines of reasoning on this issue. The first (not surprisingly) is viewed through the prism of international law. In the Bleiras case, ${ }^{40}$ decided in early 2006, in which national courts refused civil jurisdiction on the grounds that the dispute did not fall within the scope of special jurisdiction under the Brussels Regulation, the appellant claimed that the national Civil Procedure Code should apply instead of the Regulation. In this case the LSC was thus forced to analyse the relationship between the

38 Case 283/81 Srl CILFIT and Lanificio di Gavardo SpA v Ministry of Health [1982] ECR 3415 para 16.

39 Judgment of 27 September 2004 in UAB Samsonas v AB Paneriu investicijos, no 3K-3$461 / 2004$.

40 Judgment of 6 March 2006 in Bleiras, no 3K-3-170/2006. This judgment was adopted a week earlier than the judgment (n 18) in which the Constitutional Court confirmed that according to the Constitution (ie the Constitutional Act) EC law should prevail in the event of a conflict. 
Regulation and the national code. Although the Court naturally granted primacy to the Regulation, its reasoning was fairly awkward. It began with the general observation that procedure in international civil proceedings is regulated both by national law and international treaties, and that the Civil Procedure Code applies to such proceedings unless a bilateral or multilateral agreement to which Lithuania is a party provides otherwise. The Court then went on to state that Lithuania had become a Member State of the EU based on a multilateral treaty which empowers EU institutions to adopt various legal acts. Based on this, the LSC drew the conclusion that, pursuant to this international treaty, the Brussels Regulation is a source of law in civil proceedings and, therefore, should apply in situations falling within its scope. This line of reasoning is quite concise, and helps the LSC reach the desired result; however, it confirms the obligation to apply EC law in a roundabout way, rather than relying on EC law itself, or at least on the national constitution.

The second line of reasoning is based on national provisions for the application of Community law. In the Dekont case ${ }^{41}$ the Court was faced with the opposite situation to that above, ie one in which the lower courts had applied the national Civil Procedure Code instead of the Regulation on the Service of Judicial Documents. ${ }^{42}$ In this case (which, like the previous one, dealt with 'European civil procedure'), the LSC followed a logic whereby the Regulation was to be applied not because it proceeds from an international treaty, but simply because the Civil Procedure Code (in its 'accession articles', as mentioned above ${ }^{43}$ ) states that EC law should apply in civil proceedings. This change in reasoning may have been influenced by the decisions of the Constitutional Court, ${ }^{44}$ which cited the Constitutional Act and pointed out that EC law is an integral part of the legal system and must be applied. However, it could also represent merely another inconsistency in reasoning among the LSC's different chambers.

In this same case, the LSC also dealt for the first time with the supremacy of EC law. The Court annulled the lower court decisions on the grounds that, by applying national law instead of an EC regulation, they failed to grant primacy to Community law. However simple this case may appear (for it is obvious that, having a directly applicable regulation, a national court should apply it, rather than a provision of a national law), it is laudable that the Court at least mentioned the primacy of EC law. In earlier cases it had referred to provisions of Community law mainly when these confirmed what was stated by the provisions of national law, and so

\footnotetext{
41 Judgment of 29 December 2006 in Dekont, no 3K-3-690/2006.

42 Council Regulation (EC) 1348/2000 on the service in the Member States of judicial and extrajudicial documents in civil or commercial matters [2000] OJ L160/37.

43 Law on Courts (n 12).

44 See $n 18$.
} 
questions of conflict or supremacy had never been touched upon. As one would expect, of course, the LSC was not precise as to the grounds from which this supremacy proceeds. It referred neither to the ECJ's case law, as the basis of primacy in EC law, nor to the Constitutional Act and the case law of the Constitutional Court, ${ }^{45}$ as the basis of primacy in national law. Therefore, while employing the principle of the supremacy of Community law for the first time, the Court accepted it as a natural and self-evident principle, such that no precise reasoning was needed to support it.

Despite the fact that the LSC's application of EC law deserves much criticism, the development of its case law regarding intellectual property rights permits a more optimistic view. Bearing in mind that trademark law was the first area in which the LSC applied EC law, it has now developed a fairly comprehensive argumentation and reasoning based on issues related to Community law and on ECJ and CFI practice. Since late 2005, the LSC has constantly referred to the newer case law of the ECJ, the CIF and also the OHIM in trademark cases, shifting from citation of very basic concepts and definitions (eg the definition of 'average consumer ${ }^{46}$ ) to more particular aspects of trademark law (eg the specifics of three-dimensional trademarks ${ }^{47}$ ). A slow but steady improvement in reasoning based on EC law in trademark cases, reflected in an increasing use of case law and a more detailed analysis of the real meaning and context of the given EC law provisions, permits the assumption that a more coherent and correct application of EC law might be extended to other areas of the Court's jurisdiction as well. The areas of law where improvement may be seen next would presumably be those regarded as the second and third largest groups of cases: namely, the application of European civil procedure, and public procurement contracts.

\section{EU Administrative Law}

Administrative law is undoubtedly one of the most important areas of application of EC law in Lithuania, in that its regulation has been broadly influenced and amended by various EC legal instruments. Therefore, it is not surprising that connections to EC law can be found in the decisions of the state authorities and administrative courts. Before focusing in depth on one such area, competition law, a more general overview of the importance and role of EC law in the decisions of the Lithuanian Supreme Administrative Court (LSAC) will be given.

\footnotetext{
45 Ibid.

46 Judgment of 7 January 2003 in P.A. Smirnova $v$ Guiness UDV North America, no 3K-3$167 / 2003$

47 Judgment of 2 May 2006 in Latuijas Balzams, no 3K-3-275/2006; Judgment of 23 March 2005 in Unilever N.V. v UAB Varta, no 3K-3-150/2005.
} 
Before Lithuania's accession to the European Union in May 2004, the LSAC had already started to explore EC law in its decisions. According to its own official data, in the 2001 - 2004 period the LSAC made use of provisions and principles in the area of European human rights, ${ }^{48}$ and referred to conventions protecting fundamental rights in 45 of the cases it decided. ${ }^{49}$ This trend has continued in the past few years as well. ${ }^{50}$ Besides this, EC law has been referred to since the year 2002 in some decisions, especially in the area of competition law. ${ }^{51}$

In 2003, shortly before accession, the Court issued a quite critical evaluation that the application of EC law in the areas of taxation, customs, competition, health protection, environmental protection and agriculture would be very difficult without strong specialisation in these areas, due to their detailed regulation. In order to be well prepared for this challenge, the Court formed a department with special competence in all cases where aspects of international law were involved. Continuing education for judges had already begun in 2003, with a special library also founded for that purpose. ${ }^{52}$ Contacts were established with other, more experienced administrative courts, such as those of Sweden and Finland, so that Lithuanian courts could learn from their experience. ${ }^{53}$

After Lithuania's accession to the European Union, both the intensity and quality of the LSAC's application of EC law improved. In its 2004 annual report, the Court stated that becoming a member of the European Union court system was the most important event for it in that year, since from then on it not only had the right and obligation to apply EC law, but also obligations towards the EU itself, namely, contributing to the development of EC law through its jurisdiction. ${ }^{54}$ It should be said that the LSAC has shown some awareness of the meaning of EU accession in its reports. In 2004 it evaluated its own application of EC law and the principles developed in practice by the ECJ as 'good practice' for

48 See eg Judgment of 9 November 2004 in A. Songaila v Lietuvos Respublikos vidaus reikaluministerija, no $\mathrm{A}^{3}$-750-2004.

49 Lietuvos Vyriausiasis Administracinis Teismas Metinis Pranešimas 2004 [2004 Annual Report of the Lithuanian Supreme Administrative Court] <http://www.lvat.lt/default. aspx?item=mpran\&id=5853> accessed 15 April 2007.

50 See eg Judgment of 14 April 2006 in L.G. v J.K. and V.V., no N3-443/2006.

51 For a broader discussion, see the section on competition law below.

52 Lietuvos Vyriausiasis Administracinis Teismas Metinis Pranešimas 2003 [2003 Annual Report of the Lithuanian Supreme Administrative Court] <http://www.lvat.lt/default. aspx?item=mpran\&id=5807 $>$ accessed 15 April 2007; Lietuvos Vyriausiasis Administracinis Teismas Metinis Pranešimas 2005 [2005 Annual Report of the Lithuanian Supreme Administrative Court] <http://www.lvat.lt/default.aspx?item=mpran\&id=5885> accessed 15 April 2007.

532004 Annual Report (n 49) and 2005 Annual Report (n 52).

542005 Annual Report (n 52). 
interpreting and clarifying national law provisions, ${ }^{55}$ although there was neither an indication of what the term 'good practice' meant nor when and on what grounds the Court had applied such 'good practice'. In its 2005 annual report, the LSAC further stated that it had directly applied EC law in more than 20 cases in $2005 .{ }^{56}$ According to this report, it had applied EC law especially intensively in the areas of taxation and competition law.

Despite all the LSAC's efforts and the importance it assigns to correctly applying EC law, as well as judges' ongoing education and participation in seminars, conferences and projects, difficulties concerning the status, interpretation and application of EC law are still encountered today. When assessing the practical results of the Court's application of EC law, however, one should bear in mind that the whole system of administrative courts in Lithuania began functioning only in the year 1999, and that the LSAC started working only in 2001. Thus administrative courts have had to clear a double hurdle: while they were still gaining experience in applying administrative law in general, a totally new system of law, ie EC law, now had to be applied. Their experience with administrative law as a separate legal area, as well as with its application, must still be regarded as small compared to that of other EU Member States.

Some examples of the LSAC's practice will show the positive and negative sides of the 'use' of EC law in its judgments. Both shortly before and soon after accession, the Court took into account the application of relevant general principles of EC law in certain cases concerning the development of general principles under Lithuanian law. One example was its interpretation of the principle of proportionality, where it stated that this principle is not solely a national principle, but also one developed by the ECJ's jurisprudence. It therefore clarified certain national provisions by reference to those under EC law and one judgment by the ECJ ${ }^{57}$ Likewise, when discussing the principle of fiscal neutrality and defining its essence, the LSAC referred to a decision by the ECJ. ${ }^{58}$ When the content of the principle of non-discrimination ${ }^{59}$ also needed to be clarified, reference was made to Art $12 \mathrm{EC}$ and one case decided by the ECJ, thus establishing the content of this principle in the Lithuanian Civil Code. Although the given case was not connected to EC law, the

\footnotetext{
55 Ibid.

562005 Annual Report (n 52).

57 Judgment of 20 February 2004 in Bité GSM v Ryšiu reguliavimo tarnyba prie Lietuvos Respublikos Vyriausybés, no A ${ }^{1}-362-2004$.

58 Judgment of 27 January 2004 in UAB 'Tauja' $v$ Valstybinè mokesčiu inspekcija, no $\mathrm{A}^{1}$ 355-2004.

59 Judgment of 28 January 2004 in $A B$ 'Žemaitijos pienas' $v$ Žemès ūkio ministerija, no $\mathrm{I}^{1}$ 08-2004.
} 
Court noted that the principle's content under EC law was similar to that defined in the Constitution of the Lithuanian Republic. In all these cases, the LSAC's good intention to apply Lithuanian law in accordance with European law may be recognised. However, it is not very clear why and on what grounds the LSAC decided to refer to European principles in cases concerning the interpretation of purely national law, and what kind of systematic approach it followed in so doing. This has not only led to unclearness and non-transparency, but also creates the impression that EC law was chosen unsystematically in order to apply national law where its provisions and/or principles were insufficient or not yet developed to the necessary extent.

New national laws on taxation came into force on the day of Lithuania's accession to the EU, and several cases soon arose concerning VAT. The disputes in some of these cases had begun even before European legislation came into force in Lithuania. Nevertheless, in several such cases the Court used EC directives concerning VAT as 'secondary sources' to clarify the essence of VAT provisions in national legislation. ${ }^{60}$ The LSAC did take into account the fact that EC law was not in force at the time when the dispute arose. However, it did not further define the term 'secondary sources' or their exact role, but rather simply used them as an interpretative tool. The same can be observed for customs regulations, since the entire customs regime changed upon accession to the European Union. ${ }^{61}$ In reviewing these cases, one has the impression that the LSAC again took advantage of the principles and interpretation of EC law to define the essence of the corresponding national principles and provisions and interpret them.

One more interesting example from the beginning of 2006 may be cited here, in which the LSAC again had to decide a case concerning VAT issues. The Court referred to Directive 77/388/EC to define the term 'tax unit' with respect to VAT payments, stating that, in order to ensure uniform interpretation throughout the EU (which was the Directive's aim), the provisions of national law had to be defined according to the Directive and its interpretation in ECJ case law. The LSAC further extensively discussed not only the provisions of the Directive but also the latest ECJ

\footnotetext{
60 See UAB 'Tauja' $v$ Valstybiné mokesčiu inspekcija (n 58), Judgment of 9 February 2006 in Ignalinos atominè elektrinè $v$ Valstybinè mokesčičių inspekcija, no A ${ }^{4}-779 / 2006$, and Judgment of 6 February 2006 in Galintai ir partneriai $v$ Valstybine mokesčičiu inspekcija, no $\mathrm{A}^{1}-794 / 2006$, where the Court stated that although the relevant EC law had no force in Lithuania at the time when the conflict arose, and can therefore only be used as a secondary tool for interpreting national provisions, the EU provisions and ECJ case law were applicable at the time when the case was decided.

61 See eg Judgment of 17 November 2004 in S. Žarskus $v$ VRM Šiauličių rinktine, no N9-9612004; Judgment of 9 November 2005 in UAB 'Galinta ir partneriai' prieš Muitinés departamentčią prie Lietuvos Respublikos finansčiu ministerijos, no $\mathrm{A}^{14-1699 / 2005 .}$
} 
judgments based thereon. ${ }^{62}$ This can be seen as a sign of real development and a new practice in which ECJ cases are not just referred to in order to support the Court's position; rather, the arguments contained therein are given due consideration, and the Court seeks to interpret and apply national law in light of EC law and practice.

In another case concerning application of the TIR Convention, the Court, with the help of the ECJ's judgment in case C-266/01, ${ }^{63}$ examined whether the relation between the parties to the case were of a civil or an administrative nature. The Court referred to ECJ case law at the very end of its judgment, as proof that the arguments and principles it had developed were going in the right direction. Disregarding the fact that the ECJ came to rather the opposite conclusion from the LSAC in its judgment (based, of course, on a different factual situation), the LSAC only briefly examined the statements supporting its reasoning. However, it might have been more helpful if the Court had referred to the relevant ECJ judgment earlier, and afterwards pointed out the different facts in the case before it. ${ }^{64}$

In a case brought against the Lithuanian authority administering the European agriculture and rural development programme (SAPARD), the LSAC had to define a 'long-term village resident', ie a person eligible for receiving funds under the programme. ${ }^{65}$ The Court defined this term according to an interpretation of the corresponding term 'long-term inhabitant' in the Lithuanian Civil Code. Here one might ask whether it would not have been better for the Court to find a uniform European interpretation to apply the programme in a uniform European way, instead of resorting to an interpretation of national provisions. ${ }^{66}$

At the end of 2005, the LSAC decided to seek a preliminary ruling under Article $234 \mathrm{EC}$, asking the ECJ whether the wording of the Lithuanian provision implementing Article 27 paragraph 1 of Directive 92/83/EC was in conformity with the Directive. ${ }^{67}$ The LSAC thus became

62 See Judgment of 6 February 2006 in Galintai ir partneriai v Valstybinè mokesčiu inspekcija, no $\mathrm{A}^{1}-794 / 2006$.

63 Case C266/01 Préservatrice foncière TIARD SA v Staat der Nederlanden [2003] ECR I4867.

64 Judgment of 25 November 2005 in Lietuvos nacionalinè vežèjų automobiliais asociacija 'Linava' prieš Muitinés departamenta prie Lietuvos Respublikos finansų ministerijos, Kauno teritorine muitine, no $\mathrm{A}^{14}-1479 / 2005$.

65 Judgment of 10 June 2005 in Asociacija 'Macevičiu palivarko bendruomenè' prieš Nacionalinę mokèjimo agentūrą prie Žemés ūkio ministerijos, no $\mathrm{A}^{6}$-16/2005.

66 Another case on infringement of the conditions of this same programme was decided in 2006; see Judgment of 20 February 2006 in Daumantu skanéstai v Nacionaliné mokéjimo agentūra, no $\mathrm{A}^{2}-687 / 2006$.

67 Judgment of 20 December 2005 in UAB 'Profisa' $v$ Muitinés departamentaprie Lietuvos Respublikos finansuministerijos, no $\mathrm{A}^{15}$-1292/2005. 
the first national court to make use of the procedure under Article 234 EC. ${ }^{68}$

Concluding this overview of administrative law, it may be said that, while the application of EC law has changed for the better in certain areas of law, the situation still cannot be called satisfactory. There is still no clarity regarding the application of EC law in cases that arose before May 2004. While the Court invokes EC law more often, the grounds for applying it are not always clear, and its application is still not done in the correct manner.

\section{In Focus: Competition LaW69}

Like many of the new Member States, Lithuania also had to undergo serious legal changes in the field of competition law following independence, due to the establishment of a totally new economic system. ${ }^{70}$ The Competition Law had already been adopted in 1992, 12 years before the country's accession to the EU, and a public authority had been empowered to supervise its application. As a result of the Europe Agreement, this law was amended two times, in 1999 and $2004 .{ }^{71}$ Today the institution responsible for supervising application and enforcement of the Competition Law is the Lithuanian Competition Council. ${ }^{72}$ Decisions by the Council can be appealed to the Vilnius Regional Administrative Court ${ }^{73}$ and the Lithuanian Supreme Administrative Court. ${ }^{74}$

\footnotetext{
68 On 19 April 2007 the ECJ decided in case C-63/06 that the concerns of the LSAC were justified, ruling that the Lithuanian provision violated Directive 92/83/EC. Hopefully this will be an incentive for Lithuanian courts to use the possibility of reference under Art 234 EC more often - but only when there is really a need, and after having analysed the relevant EC law in detail themselves.

69 In this section, the authors focus on decisions adopted on the basis of Articles 81 and $82 \mathrm{EC}$ and the corresponding Lithuanian provisions. There are several decisions by the LCC and the LSAC in the area of unfair competition, especially advertising, in which EC law was applied in order to define terms in Lithuanian laws and establish their proper application; see eg Judgment of 17 November 2005 in UAB 'Tele 2' $v$ Lietuvos Respublikos konkurencijos taryba, no $\mathrm{A}^{1}-931 / 2005$, where the term 'consumer' was defined in a case of misleading advertising.

70 See also Jens Hölscher \& Johannes Stephan, 'Competition Policy in Central Eastern Europe in the Light of EU Accession' (2004) 42 JCMS 323, 325.

71 Amended in 1999 (Official Gazette 1999, no 30-856) and in 2004 (Official Gazette 2004, no 63-2244).

72 Hereinafter also LCC.

73 See www.vat.lt.

74 See www.lvat.lt.
} 


\section{Application of EC Law before Accession}

From the very outset, the LCC chose a progressive approach to implementing and applying European Community law. ${ }^{75}$ As one of the reasons justifying this approach, the LCC referred to the Lithuanian Constitution, whose Article $47^{76}$ contains the principle of protecting the freedom of fair competition. Therefore, it stated, neither the LCC nor the relevant courts faced any dilemma about making trade-offs among conflicting objectives. ${ }^{77}$

Despite the fact that the only 'obligation' to consider EC law was contained in Article 1 paragraph 3 of Lithuania's Competition Law, which states that the Law's aim is harmonisation with EC competition law, as early as 2000 the LCC had begun to rely on EC law in its decisions. Five of its seventeen published decisions in the 2000 - 2003 period can be seen to make reference to the practice of the ECJ and the Commission. In its very first decision against Lithuanian Telecom, which was followed by several others, ${ }^{78}$ the LCC referred mainly to ECJ case law, stating that one of the aims of the national law was harmonisation with EC law. ${ }^{79}$

The reasoning in these decisions was usually very brief, with only a little attention devoted to legal arguments, ${ }^{80}$ while the basis of the Council's reasoning in European practice has more or less been repeated in a pragmatic, standardised way. At that time, application of EC law consisted mainly in reference to one or two European decisions, without any deeper analysis - or even any at all - of these decisions and the related facts in the case before the Council. In some of its decisions, the LCC applied the same principles established by the provisions of EC competition law without, however, making any reference to it. For example, in a case against two petrol stations concerning a concerted practice on a price-fixing cartel, ${ }^{81}$ the LCC did not refer to EC law or ECJ decisions in its own ruling, although that would have been very helpful, as this was one of the first decisions in Lithuania whose subject was a concerted practice. When the case was brought before the administrative courts, the Council

\footnotetext{
75 The aim of harmonising Lithuanian competition law and policy with EC law was already enshrined in Art 1 para 3 of the 1999 version of the Competition Law.

76 Art 46 of the Lithuanian Constitution (Official Gazette 1992, no 33-1014).

77 'The Objectives of Competition Law and the Optimal Design of a Competition Authority within the Overall Government', OECD Global Forum on Competition $2003<\mathrm{http}$ ://www. konkuren.lt/english/international/oecd.htm> accessed 28 November 2006.

78 Eg Decision of 18 May 2001 in Mažeikių nafta, no 8/b.

79 This was additionally based on Article 64 of the Europe Agreement.

80 Although not included in this article, the same can be said for merger decisions by the LCC, although it could be argued that this approach does follow the Commission's practice in merger cases.

81 Decision of 28 December 2000 in Lietuvos kuras, no 18/b.
} 
referred to the need to harmonise Lithuanian law with EC law, basing its argumentation on the latter during the appeal. ${ }^{82}$ Notwithstanding the LCC's argumentation referring to EC law in several such cases, the administrative courts hearing appeals against LCC decisions in most of the cases brought between 2000 and 2004 - and, in fact, upholding those decisions - did not mention or consider the Council's arguments relating to EC law in their reasoning. ${ }^{83}$

However, two more positive examples can be found.$^{84}$ In one of these cases, the application of EC law as such was in dispute, based on the argument that, according to Article 138 of the Lithuanian Constitution, EC law could not be applied because it is regarded as international law which has not been ratified by the Parliament of the Republic of Lithuania, and therefore has not become part of the Lithuanian legal system. The LSAC replied that no international legal acts had been applied in violation of the Constitution, since the LCC referred to EC law only as a tool for interpreting Lithuanian legal provisions in an international context, which only showed that the LCC had reviewed the case exhaustively and from all sides. ${ }^{85}$ The LSAC further stated that Lithuanian law did not prohibit reference to EC law and that, besides, EC law had been applied not as binding law, but rather as law having the character of a recommendation. ${ }^{86}$

When reviewing judgments by administrative courts from this period, the reasons behind their statements are often unclear, either because well-founded argumentation is lacking or the courts simply confirm the Council's decisions without an adequate explanation. ${ }^{87}$ This led to nontransparency and legal uncertainty regarding the application and validity of EC law during this period. However, it can also be observed that in most national cases little attention was devoted in written decisions to legal reasoning in general or the arguments made by the parties. Other

\footnotetext{
82 Judgment of 3 December 2002 in AB 'Lietuvos kuras' v Lietuvos Respublikos konkurencijos taryba, no I-1045-2001.

83 Three examples where EC law was not even mentioned, although the LCC had referred to it: Decision of 11 April 2002 in Dèl AB 'Klaipédos jūru kroviniu kompanija' veiksmu atitikimo Konkurencijos $\dot{i}$ statymo 9 straipsnio 3 punkto reikalavimus, no 5/b; Decision of 28 December 2000 in Dél ímoniu veikiančiu fotografavimo paslaugu rinkoje, veiksmu atitikimo Konkurencijos istatymo Nr. VIII - 10995 straipsnio 1 dalies 1 punkto nuostatoms, no 19/b; Judgment of 27 June 2001 in $A B$ 'Lietuvos telekomas' $v$ Lietuvos Respublikos konkurencijos taryba, no A-612-01.

84 See Judgment of 16 May 2002 in Specializuota komplektavimo valdyba, no A-451/2002; Decision of 21 February 2002 in Lietuvos telekomas, no 2/b; Judgment of 11 June 2003 in Lietuvos telekomas, no A-530/2003.

85 Judgment of 11 June 2003 (n 84).

86 Judgment of 16 May 2002 (n 84).

87 More broadly, see Y Goldammer \& E Matulionyte, 'The Application of European Union Law in Lithuania' (2006) 31 EL Rev 260-270.
} 
reasons for the inadequate application of EC law might include the differing level of knowledge of EC law in the Lithuanian Competition Council, compared with that of Lithuanian courts, since at a very early stage (in 1999) the Council had started exchange projects with the European Commission, OECD and twinning programmes, ${ }^{88}$ which it considered the best way of supporting effective implementation of competition policy and enforcing the law with regard to the acquis communautaire. ${ }^{89}$ Although long-term training seminars for judges in all branches of the court system did exist, these programmes amounted to only 26 hours in 2004, while in 2005 no separate seminars on European Community law were planned, ${ }^{90}$ although these EC law seminars have continued in 2006 and 2007. For judges used to reviewing cases under national law, another totally new situation arose following the introduction of a separate administrative court system. This led to a certain reluctance to apply unknown legal sources and instruments, ${ }^{91}$ as may be seen in several judgments where the courts decided cases on different legal grounds than those found in EC law. ${ }^{92}$

\section{Application of EC Law since Accession}

Only slight changes can be observed following accession in 2004, as well as at the beginning of 2005 . However, the beginning of a truly positive change can be found in the LSAC's decision of June 2004 concerning the abuse of a company's dominant position in the Lithuanian mineral oil market. ${ }^{93}$ For the first time, the Court responded more extensively to the parties' arguments, also taking into consideration the practice of European institutions and the application of principles enshrined in EC law when evaluating the arguments of the lower court. Referring to the

\footnotetext{
88 PHARE project 'Support to European Integration in Lithuania' and PHARE twinning project 'Strengthening Enforcement of Competition Policy', Annual Report 2000, Foreword <http://www.konkuren.lt/english/annual/2000.htm> accessed 15 April 2007.

89 'Technical Assistance. General Overview', Lithuanian Contribution to OECD Global Forum 2002 <http://www.konkuren.lt/english/international/oecd.htm> accessed 15 April 2007.

90 Decision of the National Court Administration of 16 January 2004 (no 178) on the 2004 Judges' Training Programme <http://www.teismai.lt/savivalda/nutarimai_visi.asp> accessed 30 March 2007; see also recommendation by the EU Accession Monitoring Program of the Open Society Institute, 'Monitoring the EU Accession Process: Judicial Capacity 2002', 151 <http://www.eumap.org/reports/2002/judicial> accessed 30 March 2007. In its Annual Reports, the Commission has recommended improvements in this sector in both 2002 and 2003 (COM (2002) 0700 final and COM (2003) 0675 final).

91 Valančius (n 3) 29.

92 Also interesting is the Judgment of 13 September 2002 in AB 'Klaipédos jūru kroviniu kompanija', no A-871-02.

93 Decision of 18 May 2001 in Mažeikiųnafta, no 8/b; Judgment of 3 June 2004 in UAB 'Lukoil Baltija', no P-82/2004.
} 
aim of Lithuania's Competition Law under its Article 1 paragraph 3, ie harmonising national and EC competition law, the Court stated that actions prohibited under the Law, namely, prohibited agreements and the abuse of a dominant position, have a differing legal content. Further, it explained the definition of prohibited agreements under Article 5 of the Law and the abuse of a dominant position under its Article 9, also referring to the corresponding Articles 81 and 82 of the EC Treaty. Another case was concerned with the Lithuanian Post's abuse of its dominant position. Here the LCC did not invoke EC cases or laws in its decision. However, as in previous cases, arguments made during the appeals were based on cases decided at the EU level. Unlike in many previous cases, both the Vilnius Regional Administrative Court and the LSAC responded to these arguments, additionally applying EC legal sources, directives concerning postal services, and Commission decisions ex officio. ${ }^{94}$ This positive development has continued since then, and the amount of decisions cited and EC law analysed is growing. ${ }^{95}$

One very interesting decision adopted by the LCC in 2006 concerned a concerted practice in the Lithuanian paper market. The LCC not only examined this practice under Article 5 of Lithuania's Competition Law, but also applied Article $81 \mathrm{EC}$ directly to the national law. Its extensive argumentation focused on direct application of Article $81 \mathrm{EC}$ and the effect on trade among Member States in the case. Since the concerted practice had existed since 1999, however, Article 81 could be applied directly only after 1 May 2004, and thus activities after May 2004 were examined separately. ${ }^{96}$

The cases decided by the LCC in 2007 have so far mainly concerned prohibited agreements during a public tender. ${ }^{97}$ The interpretation of national competition law provisions is always combined with reference to EC competition law cases regarding Article $81 \mathrm{EC}$, stating that national law is identical in substance to the EC provisions, and that interpretation

94 Decision of 5 January 2006 in Dèl AB 'Lietuvos paštas' veiksmuatitikties Lietuvos Respublikos konkurencijos istatymo 9 straipsnio reikalavimams, no 2S-01; Judgment of 22 December 2006 in Lietuvos Paštas v Konkurencijos Taryba, no A²-2207/2006.

95 Decision of 5 May 2005 in Dèl Taksi paslaugu teikèjųasociacijos, no 2S-3; Judgment of 11 May 2006 in UAB 'Taksvija' a.o. $v$ Konkurencijos Taryba, no A ${ }^{1}-686 / 2006$.

96 Decision of 26 October 2006 in Dèl popieriumi prekiaujančiuūkio subjektų veiksmų atitikties Lietuvos Respublikos konkurencijos istatymo 5 straipsnio ir Europos Bendrijos steigimo sutarties 81 straipsnio reikalavimams, no 2S-13.

97 Decision of 15 March 2007 in Dèl ūkio subjektų, dalyvavusiu Klaipédos miesto savivaldybès švietimo istaigu ūkio tarnybos 2005-2006 m. organizuotuose vieščju pirkimu konkursuose, veiksmu atitikties konkurencijos istatymo 5 straipsnio reikalavimams, no 2S-6; the same can be said for the Decision of 1 February 2007 in Dél ükio subjektų, dalyvavusiu šilumos punktu keitimo darbu konkurse, veiksmu atitikties Konkurencijos istatymo 5 straipsnio reikalavimams, no $2 \mathrm{~S}-3$. 
of EC law may thus serve as an example when reviewing the situation in Lithuanian cases.

All of the LCC's more recent decisions, especially that of 26 October $2006,{ }^{98}$ show a growing self-confidence, willingness and understanding concerning the application of EC law in the area of competition law. One can, therefore, observe a tendency towards ever-increasing application of EC law, in terms of both quality and quantity.

\section{Conclusion}

Having summarised the application of EC law by the Lithuanian Supreme Court in the area of civil jurisdiction, particularly intellectual property rights, on the one hand, and the Lithuanian Supreme Administrative Court and the Lithuanian Competition Council, with a special focus on competition law, on the other, the authors conclude that the application of EC law in the areas under consideration is far from ideal. In most cases, courts have not yet developed a general view of Community law as a sui generis system of law. There are still difficulties in distinguishing between EC law and ordinary international law. Instead of referring to the specific nature of EC law, which is accepted in both constitutional jurisprudence and national legislation, courts treat EC law as something analogous to international law. The principles set forth by the ECJ concerning the 'ideal' application of Community law by the national judiciary have apparently not yet been fully comprehended by Lithuania's courts. While they seem to have learned that supremacy must be given to EC law, in most cases they are unable to consistently incorporate reasoning based on such supremacy into their judgments.

However, when these two 'pioneer' fields of EC law application are analysed, it is obvious that changes are gradually occurring. The first examples of application by both supreme courts were very poor ones, lacking a systematic approach to application and insufficient in both quality and quantity. The development of case law in trademark disputes permits a more positive evaluation, while in the area of competition law EC law has begun to be applied much more purposefully. ECJ case law is being referred to, and arguments by the parties based on EC law are given due consideration. Still, these two areas represent the most well-developed ones, while similar progress has not yet been seen in other fields of EC law. Hopefully, satisfactory practice in the fields considered here will spill over into a more general awareness of EC law and, accordingly, its proper application. Since 'the will' to apply EC law seems to exist on the part of national courts and institutions, 'the way' to apply it correctly must also be found. For the moment, the way is time, training and practice.

98 Decision of 26 October 2006 (n 96). 